\title{
被
}

Contents lists available at www.ijpba.in

International Journal of Pharmaceutical and Biological Science Archive

NLM (National Library of Medicine ID: 101738825)

Index Copernicus Value 2019: 71.05

Volume 9 Issue 1; January-February; 2021; Page No. 79-92

\section{DESIGN, OPTIMIZATION \& IN-VITRO EVALUATION OF SODIUM ALGINATE BASED IN- SITU GEL OF RANITIDINE HYDROCHLORIDE IN ULCER TREATMENT}

\author{
Sanket Kumar ${ }^{1}$, Mahesh Singh ${ }^{2}$, Babulal Patel ${ }^{3}$ \\ ${ }^{1}$ Assistant Professor, Dept. of Pharmaceutics, G. D. Memorial College of Pharmacy, Jodhpur, Rajasthan \\ (India) \\ ${ }^{2}$ Assistant Professor, Dept. of Pharmacology, G. D. Memorial College of Pharmacy, Jodhpur, Rajasthan \\ (India) \\ ${ }^{3}$ Assistant Professor, Dept. of Pharmaceutics, G. D. Memorial College of Pharmacy, Jodhpur, Rajasthan
} (India)

Conflicts of Interest: Nil

Corresponding author: Sanket Kumar

DOI https://doi.org/10.32553/ijpba.v9i1.178

\begin{abstract}
Peptic ulcer, it is the most common type of stomach disease, according to the American Gastroenterology Association. "We know that ulcers occur because there has been a disruption in the balance of factors that injure the digestive tract and those factors that protect it from injury," The present investigation deal with the formulation, optimization and evaluation of sodium alginate based in situ gel of ranitidine hydrochloride (R$\mathrm{HCl}$ ) in ulcer treatment. The in-situ formulation are homogenous liquid when administration orally and become gel at the contact site. The evaluation of the formulation is dependent upon accurate results obtained by analytical method used during the study. Accurate results require the use of standard and a calibration procedure. Hence, standard plots of Ranitidine hydrochloride were prepared in (0.1N HCL, pH 1.2) solutions. Two, sodium alginate and calcium carbonate used as a polymer and cross-linking agent respectively in the formulation of in-situ gel. From the IR studies it may be concluded that the drug and carriers used undergo physical interaction there is no chemical change, and thus the gelling agent, cross-linking agent and other excipient is suitable for formulation of in-situ gel of ranitidine hydrochloride. Indicate that the formulation, DKF9 which was prepared by the Sodium alginate (2 gm) with Ranitidine Hydrochloride showed minimum drug release (sustained drug release) after $8 \mathrm{hrs}$. It can be concluded that the In-situ gel was beneficial for delivering the drug which needs sustained release to achieve the slow action.
\end{abstract}

Keywords: In-situ gel, Peptic Ulcer, Ranitidine Hydrochloride (R-HCl), Sodium alginate.

\section{Introduction}

"An ulcer is a wound in the lining of the stomach or duodenum, but really any part of the gastrointestinal tract can ulcerate". When they occur in the stomach, they are called gastric ulcers. If they form in the first part of your small intestine, the duodenum, they are referred to as duodenal ulcers. It's a chronic injury where the lining has been disrupted. However, when people refer to an ulcer they are usually referring to peptic ulcer disease. ${ }^{1}$ The word peptic refers to digestion.

A peptic ulcer is the umbrella term for all types of GI ulcers. Technically an ulcer is at least 0.5 centimeters wide, but can be much larger. Duodenal ulcers mainly occur in people between 20 and 50 years old and gastric ulcers typically appear in people over age 40. Duodenal ulcers are about four times more common than gastric ulcers. ${ }^{2}$ The stomach is a very hostile environment because of the acids that help in digestion, acids that are as toxic as car battery acid. The lining of stomach and duodenum usually is well-protected from these acids by a layer of mucus. ${ }^{3}$ Peptic ulcer disease begins when a weakness in stomach or intestinal lining allows acid to create an erosion or sore in the lining. There occurs a quick elimination of certain drugs, that have been absorbed from the gastrointestinal tract (usually having short half-lives), from circulatory system due to which frequent dosing is required. To sort out this matter, innovative method gastro-retentive drug delivery systems (GRDDS) are incorporate. $^{4,5}$

They have efficient plasma drug concentration thereby reduce dosing frequency. Another highlight of this system is that it effectively reduces variations in plasma drug concentration by delivering the drug in a controlled and reproducible fashion. ${ }^{6}$ 
Ranitidine is an oral drug that blocks the production of acid by acid-producing cells in the stomach. Histamine is a naturally-occurring chemical that stimulates cells in the stomach (parietal cells) to produce acid. H2-blockers inhibit the action of histamine on the cells, thus reducing the production of acid by the stomach. Since excessive stomach acid can damage the esophagus, stomach, and duodenum and lead to inflammation and ulceration, reducing stomach acid prevents and heals acidinduced inflammation and ulcers. The FDA approved ranitidine in October 1984. ., $^{8}$

Ranitidine is used to treat ulcers of the stomach and intestines and prevent them from returning after treatment. This medication is also used to treat and prevent certain stomach and throat (esophagus) problems caused by too much stomach acid (e.g., Zollinger-Ellison syndrome, erosive esophagitis) or a backward flow of stomach acid into the esophagus (gastro esophageal-GERD). ${ }^{9}$

Oral in-situ gel forming system also known as stomach specific or raft forming systems have provided a suitable way of providing the controlled drug delivery within stomach with enhanced gastroretention. The tablet/capsule floating dosage forms are stable as compare to liquids but the problem with them is that they are needed to swallow as whole unit. ${ }^{10}$ In case of dosage adjustment these cannot be broken in halves as these are also designed for controlled release and floating ability also depends on dimensions of tablets. Elderly patients, children some adult persons and patient with certain conditions suffer from dysphasia, so it becomes difficult for them to swallow tablet/capsule dosage forms. ${ }^{11}$

\section{Materials}

Ranitidine hydrochloride (R-HCl) was obtained as gift sample from Oasis Laboratory Pvt. Ltd, (Jaipur). Sodium alginate was obtained from Signet chemical corporation (Mumbai), and Sodium Citrate, Calcium carbonate, D-sorbitol were purchased from Central drug house (P) Ltd, (Mumbai). All other chemicals and solvents used were of analytical grade.

\section{Compatibility Studies: Analysis of Ranitidine Hydrochloride (R-HCl)}

\section{Fourier Transform Infrared Spectroscopy (FTIR)}

The IR analysis of the sample was carried out for qualitative compound identification, used to record IR spectra of the prepared discs, to confirm any interaction of R-HCL with other excipients of dispersion. The pellet of approximately $01 \mathrm{~mm}$ diameter of the drug was prepared grinding 3-5 mg of sample with 100-150 mg of Potassium Bromide $(\mathrm{KBr})$ in pressure compression machine. The procedure consisted of dispersing a sample (drug alone or mixture of drug and excipients) in $\mathrm{KBr}$ and compressing into discs by applying a pressure. The pellet was placed in the light path and the spectrum was obtained. The sample pellet was mounted in IR compartment and scanned at wavelength $4000 \mathrm{~cm}^{-1}$ $-400 \mathrm{~cm}^{-1}$.

\section{Ultraviolet Spectroscopy}

Ultraviolet spectroscopy analysis of drug was carried out for wavelength maxima and absorbance determination and calibration of standard curve of drug. This was done by forming various conc. of solution $(10-60 \mathrm{mcg} / \mathrm{ml})(0.1 \mathrm{~N} \mathrm{HCl}, \mathrm{pH} 1.2)$ of drug and run the spectroscopy in the rage 200 to 400 $\mathrm{nm}$ to obtained the absorbance for their relative concentration was measured.

\section{Solubility}

Solubility Determination was performed according to Higuchi and Connors. The solubility of Ranitidine hydrochloride was determined in different solvents. An excess quantity of the drug was added in $10 \mathrm{ml}$ of each solvent in screw capped glass test tubes and shaken or 24 hours at room temperature. The solution was filtered, diluted and the solubility was determined by spectrophotometrically.

\section{Calibration Curve of Ranitidine Hydrochloride}

\section{Preparation of Buffer 0.1 N HLC (pH-1.2)}

$0.85 \mathrm{ml}$ conc. Hydrochloric acid dissolved in a100 $\mathrm{ml}$ distilled water sonicated for $10 \mathrm{~min}$. to dissolve the hydrochloric acid, and then check the $\mathrm{pH}$ at 1.2. Finally $0.1 \mathrm{~N}$ Solution (pH-1.2) is prepared and used as a blank solution.

\section{Determination of Absorption maxima}

A UV absorption maxima was determined by scanning a 10-60 ug/ml solution of Ranitidine hydrochloride in $0.1 \mathrm{~N} \mathrm{HCl}$, pH 1.2 between 200400nm.

\section{Preparation of Calibration Curve}

Ranitidine hydrochloride was found to be soluble in water and HCL. A simple reproducible method of estimation was carried out in water and HCL ranging from $10-60 \mathrm{mcg} / \mathrm{ml}$ solutions at $314 \mathrm{~nm}$ against the blank the standard graph obtained was linear, with regression coefficient $0.997 .10 \mathrm{mg}$ of Ranitidine hydrochloride was weighed accurately and dissolved $5 \mathrm{ml} 0.1 \mathrm{~N}$ HCL in a $100 \mathrm{ml}$ of volumetric flask and volume was made up to with 
the $0.1 \mathrm{~N} \mathrm{HCl} \mathrm{pH} 1.2$ to obtain a stock solution of $100 \mu \mathrm{g} / \mathrm{ml}$. The calibration curve was plotted between concentration and absorbance. ${ }^{13}$

\section{Preparation of In-situ gel of Ranitidine Hydrochloride}

SA (sodium alginate) Solution was prepared in distilled water by heating to $60^{\circ} \mathrm{C}$ under continuous stirring. After cooling below $40^{\circ} \mathrm{C}$. Ingredients including drug, gelling agent and other excipients were weighed accurately on butter paper with the help of a stainless steel then Sodium alginate solution of difference concentrations $(0.5,1,1.5,2$,
$2.5 \mathrm{gm})$ were prepared by adding the sodium alginate to distilled water containing difference concentration $(0.25 \mathrm{gm}, 0.5 \mathrm{gm})$ calcium carbonate, and difference concentration $(0.25 \mathrm{gm}, 0.5 \mathrm{gm})$ sodium citrate and heating to $60^{\circ} \mathrm{C}$ and after cooling below $40^{\circ} \mathrm{C}$ and continuous stirring. Appropriate amounts of Ranitidine hydrochloride 0.30 (gm) and flavouring agent (the optimized concentrations-0.5, 1, 2, 3, $4 \mathrm{gm}$ of D-sorbitol) were then dissolved in the resulting solution and formulation were prepared. The resulting formulations were finally stored in amber coloured bottles until further use.

Table 1: Preparation of In-situ gel of Ranitidine Hydrochloride

\begin{tabular}{|l|l|l|l|l|l|}
\hline \multirow{2}{*}{ Ingredients } & \multicolumn{5}{l}{ Formulation code and Quantities } \\
\cline { 2 - 7 } & DKF1 & DKF2 & DKF3 & DKF4 & DKF5 \\
\hline Ranitidine HCL & $300 \mathrm{mg}$ & $300 \mathrm{mg}$ & $300 \mathrm{mg}$ & $300 \mathrm{mg}$ & $300 \mathrm{mg}$ \\
\hline Sodium Alginate & $0.5 \mathrm{gm}$ & $1.0 \mathrm{gm}$ & $1.5 \mathrm{gm}$ & $2.0 \mathrm{gm}$ & $2.5 \mathrm{gm}$ \\
\hline Sodium citrate & $250 \mathrm{mg}$ & $250 \mathrm{mg}$ & $250 \mathrm{mg}$ & $250 \mathrm{mg}$ & $250 \mathrm{mg}$ \\
\hline CaCo3 & $250 \mathrm{mg}$ & $250 \mathrm{mg}$ & $250 \mathrm{mg}$ & $250 \mathrm{mg}$ & $250 \mathrm{mg}$ \\
\hline D-Sorbitol & $0.5 \mathrm{gm}$ & $1.0 \mathrm{gm}$ & $2.0 \mathrm{gm}$ & $3.0 \mathrm{gm}$ & $4.0 \mathrm{gm}$ \\
\hline Distil Water & q.s & q.s & q.s & q.s & q.s \\
\hline Total Weight (ml) & $100 \mathrm{ml}$ & $100 \mathrm{ml}$ & $100 \mathrm{ml}$ & $100 \mathrm{ml}$ & $100 \mathrm{ml}$ \\
\hline
\end{tabular}

Table 2: Preparation of In-situ gel of Ranitidine Hydrochloride

\begin{tabular}{|l|l|l|l|l|l|}
\hline \multirow{2}{*}{ Ingredient } & \multicolumn{5}{l}{ Formulation code and Quantities } \\
\cline { 2 - 7 } & DKF6 & DKF7 & DKF8 & DKF9 & DKF10 \\
\hline Ranitidine HCL & $300 \mathrm{mg}$ & $300 \mathrm{mg}$ & $300 \mathrm{mg}$ & $300 \mathrm{mg}$ & $300 \mathrm{mg}$ \\
\hline Sodium Alginate & $0.5 \mathrm{gm}$ & $1.0 \mathrm{gm}$ & $1.5 \mathrm{gm}$ & $2.0 \mathrm{gm}$ & $2.5 \mathrm{gm}$ \\
\hline Sodium citrate & $500 \mathrm{mg}$ & $500 \mathrm{mg}$ & $500 \mathrm{mg}$ & $500 \mathrm{mg}$ & $500 \mathrm{mg}$ \\
\hline CaCo3 & $500 \mathrm{mg}$ & $500 \mathrm{mg}$ & $500 \mathrm{mg}$ & $500 \mathrm{mg}$ & $500 \mathrm{mg}$ \\
\hline D-Sorbitol & $0.5 \mathrm{gm}$ & $1.0 \mathrm{gm}$ & $2.0 \mathrm{gm}$ & $3.0 \mathrm{gm}$ & $4.0 \mathrm{gm}$ \\
\hline Distil Water & q.s & q.s & q.s & q.s & q.s \\
\hline Total Weight (ml) & $100 \mathrm{ml}$ & $100 \mathrm{ml}$ & $100 \mathrm{ml}$ & $100 \mathrm{ml}$ & $100 \mathrm{ml}$ \\
\hline
\end{tabular}

\section{CHARACTERIZATION OF IN-SITU GEL}

\section{Physical Appearance and $\mathrm{pH}$}

All the prepare sodium alginate based in situ solution were checked for their clarity and the type of the solution. After administration of the prepared solution in $(0.1 \mathrm{~N} \mathrm{HCl}, \mathrm{pH} 1.2)$ also checked the time required for gel formation and type of gel formed.
The $\mathrm{pH}$ was measured in each of the solution of sodium alginate based in situ solution using a calibrated digital $\mathrm{pH}$ meter at $27^{\circ} \mathrm{C}$. The measurement of $\mathrm{pH}$ of each data was in triplicate. ${ }^{13}$

\section{Viscosity of in-situ gelling solutions}

The viscosity of formulations was determined by a Brookfield viscometer DV-III (Brookfield, USA) 
using spindle number 21 with cup and bob setting at $50 \mathrm{rpm}$.

\section{Floating behavior}

The floating ability of the prepared formulations was evaluated in $(0.1 \mathrm{~N} \mathrm{HCl}, \mathrm{pH} 1.2)$ Solution. The floating time of the prepared formulation took to emerge on the medium surface (floating lag time) was found to be $60 \mathrm{sec}$. The time the formulation constantly floated on the dissolution medium surface (duration of floating) was evaluated to be $12 \mathrm{hrs}$ resulting the formation of thick gel with good floating tendency. ${ }^{14}$

\section{In-vitro gelling capacity}

To evaluate the formulations for their in-vitro gelling capacity by visual method, solutions of in situ gel forming drug delivery system were prepared. The in-vitro gelling capacity of prepare formulations was measured by placing $5 \mathrm{ml}$ of the gelation solution $(0.1 \mathrm{~N}$ HCL, $\mathrm{pH} 1.2)$ in a $15 \mathrm{ml}$ borosilicate glass test tube and maintained at $37 \pm 1^{\circ} \mathrm{C}$ temperature. One $\mathrm{ml}$ of formulation solution was added with the help of pipette. The formulation was transferred in such a way that places the pipette at surface of fluid in test tube and formulation was slowly released from the pipette. As the solution comes in contact with gelation solution, it was immediately converted into stiff gel like structure. The gelling capacity of solution was evaluated on the basis of stiffness of formed gel and time period for which they formed gel remains as such. The invitro gelling capacity was graded in three categories on the basis of gelation time and time period for which they formed gel remains. (+) Gels after few minutes, dispersed rapidly (++) Gelation immediate remains for 12 hours (+++) Gelation immediate remains for more than 12 hours. ${ }^{14}$

\section{Drug content}

Ten $\mathrm{ml}$ of the solution was added to $900 \mathrm{ml}(0.1 \mathrm{~N}$ $\mathrm{HCl}, \mathrm{pH}$ 1.2) Solution and stirred for $1 \mathrm{hr}$. on a magnetic stirrer. The solution was filtered, suitably diluted with $(0.1 \mathrm{~N} \mathrm{HCl}, \mathrm{pH} 1.2)$ and the drug concentration was determined by using a UV-visible spectrophotometer a (Systronics 2203) at $314 \mathrm{~nm}$ against a suitable blank solution.

\section{In-vitro release studies}

An in-vitro release study was carried out using dissolution test apparatus (Lab India DT 8000,
Paddle Method). The following procedure was followed throughout the study that is shown in (table 2) to determine the in-vitro dissolution rate for the formulations. The release of ranitidine from the formulations was determined using dissolution test apparatus USP Type II with a paddle stirrer at 50 $\mathrm{rpm}$. The dissolution medium used $900 \mathrm{ml}$ of $(0.1 \mathrm{~N}$ HCL, pH 1.2) solution and temperature was maintained at $37 \pm 0.2{ }^{\circ} \mathrm{C}$. Ten $\mathrm{ml}$ of the formulation were placed into a Petridish $(4.5 \mathrm{~cm}$ i. d.) which was kept in the dissolution vessel and $0.1 \mathrm{~N}$ HCL solution was carefully added to the vessel avoiding any disturbance of the Petri dish. At each time interval, a precisely measured sample of the dissolution medium was pipetted out and replenished with fresh medium. Ranitidine hydrochloride concentration in the aliquot was determined spectrophotometrically.

\section{Drug release kinetic studies}

The drug release kinetic studies were done by various mathematical models (zero order, first order, Higuchi's square root, Hixson-Crowell cube root law and Pappas equation). The model that best fits the release data is selected based on the correlation coefficient ( $r$ ) value in various models. The model that gives high ' $r$ ' value is considered as the best fit of the release data. The release constant was calculated from the slope of the appropriate plots, and the regression coefficient $\left(\mathrm{r}^{2}\right)$ was determined.

\section{RESULT AND DISCUSSION}

\section{Analytical Profile of Ranitidine hydrochloride}

\section{FTIR Studies}

The IR analysis of the sample was carried out for qualitative compound identification, used to record IR spectra of the prepared discs, to confirm any interaction of R-HCL with other excipients of dispersion. The pellet of approximately $01 \mathrm{~mm}$ diameter of the drug was prepared grinding 3-5 mg of sample with 100-150 mg of Potassium Bromide $(\mathrm{KBr})$ in pressure compression machine. The procedure consisted of dispersing a sample (drug alone or mixture of drug and excipients) in $\mathrm{KBr}$ and compressing into discs by applying a pressure. The pellet was placed in the light path and the spectrum was obtained. The sample pellet was mounted in IR compartment and scanned at wavelength $4000 \mathrm{~cm}^{-1}$ $-400 \mathrm{~cm}^{-1}$. 


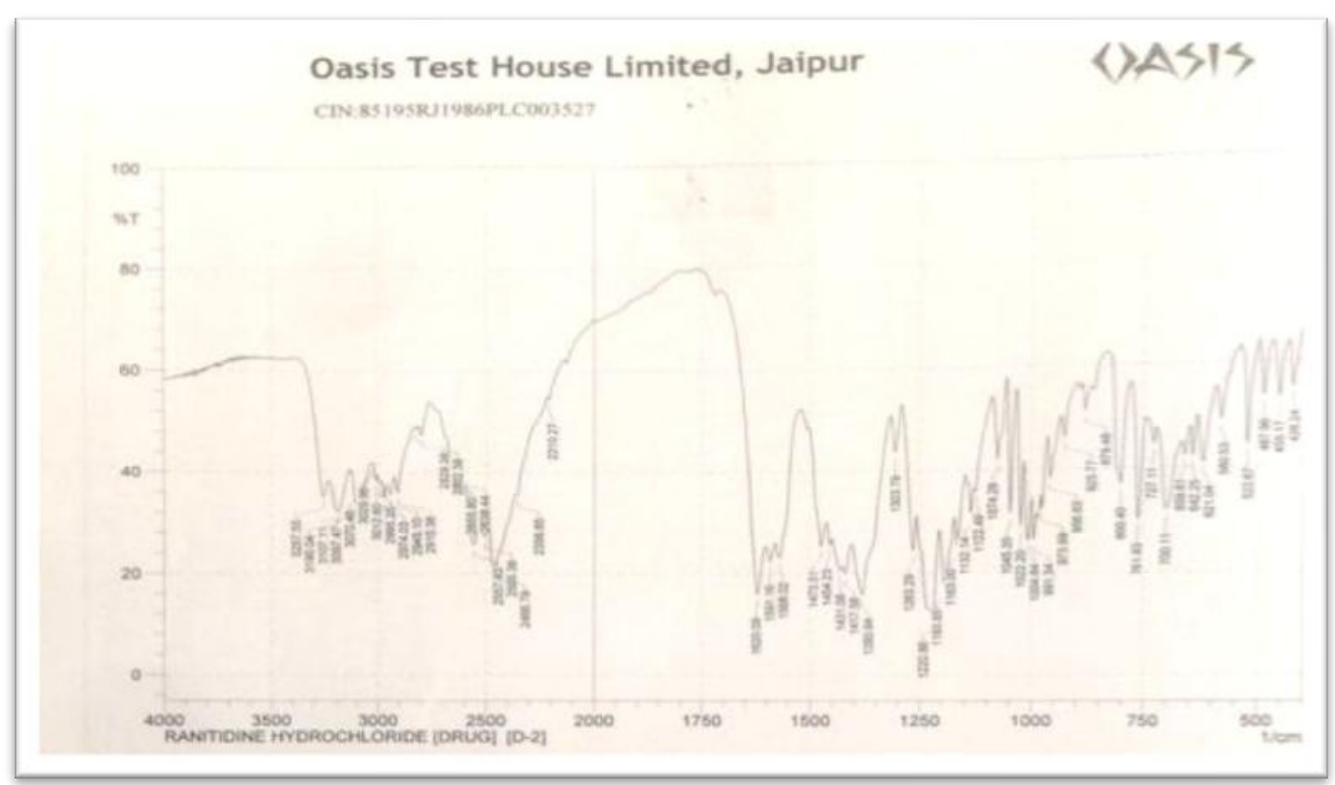

Fig.1: FTIR spectra of Ranitidine hydrochloride drug sample

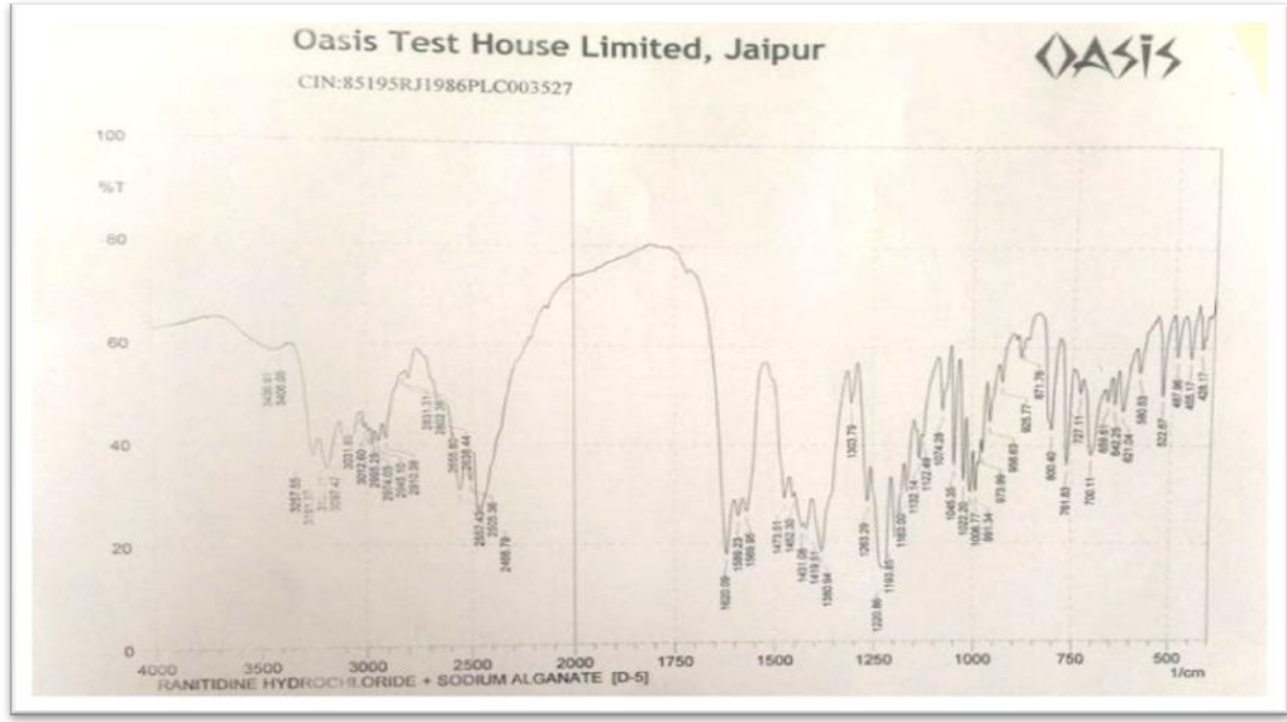

Fig.2: FTIR spectra of R-HCL drug + Sodium alginate

Determination of UV Absorbance Maxima of Ranitidine Hydrochloride

The standard stock solution was used to determination the $\lambda$ max of $(0.1 \mathrm{~N} \mathrm{HCl}, \mathrm{pH} 1.2)$ was used as blank for the study. The spectrum was taken between the UV ranges of 200-400 $\mathrm{nm}$. The highest peak obtained from the spectrum analysis was taken as $\lambda$ max for Ranitidine Hydrochloride.

Table 3: Calibration curve data of Ranitidine Hydrochloride

\begin{tabular}{|l|l|l|l|}
\hline S. No. & Conc. $(\mathbf{m c g} / \mathbf{m l})$ & Absorbance & \pm SD \\
\hline 1. & 10 & 0.382 & \pm 0.017 \\
\hline 2. & 20 & 0.492 & \pm 0.025 \\
\hline 3. & 30 & 0.627 & \pm 0.039 \\
\hline 4. & 40 & 0.788 & \pm 0.061 \\
\hline 5. & 50 & 0.931 & \pm 0.027 \\
\hline 6. & 60 & 1.053 & \pm 0.043 \\
\hline
\end{tabular}




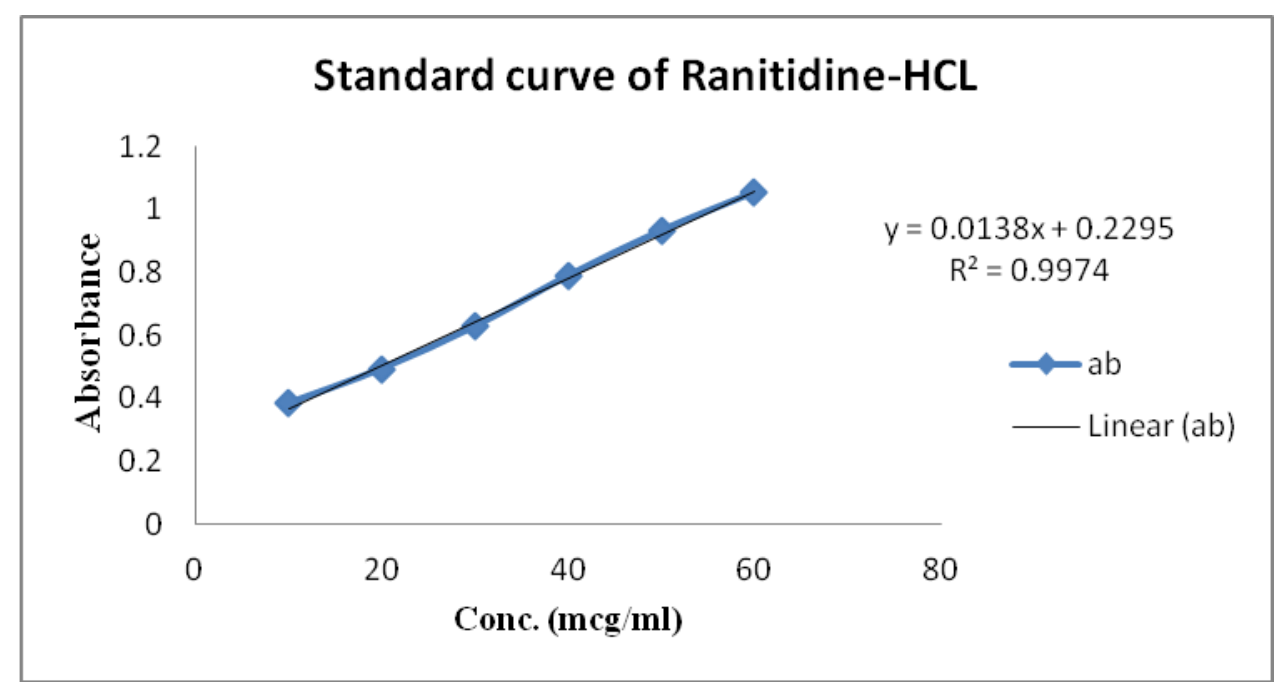

Fig.3: Standard curve of Ranitidine Hydrochloride

\section{Preparation of standard calibration curve of Ranitidine Hydrochloride}

Ranitidine Hydrochloride $(10 \mathrm{mg})$ was dissolved in $(0.1 \mathrm{~N} \mathrm{HCl}, \mathrm{pH} 1.2)$ and volume was made up to $100 \mathrm{ml}$ in $100 \mathrm{ml}$ volumetric flask. This solution $(100 \mathrm{mcg} / \mathrm{ml})$ was further diluted with $(0.1 \mathrm{~N} \mathrm{HCl}, \mathrm{pH} 1.2)$ to obtain solution of 10 to $100 \mathrm{mcg} / \mathrm{ml}$. The absorbance of each solution was measured at $314 \mathrm{~nm}$ using UV spectrophotometer. The standard curve was obtained by plotting absorbance $\mathrm{v} / \mathrm{s}$. concentration $(\mathrm{mg} / \mathrm{ml})$

Table 4: Determination of maxima wavelength $\left(\lambda_{\max }\right)$

\begin{tabular}{|l|l|l|}
\hline S. No. & Wavelength $(\mathbf{n m})$ & Absorbance \\
\hline 1. & 228 & 0.141 \\
\hline 2. & 245 & 0.298 \\
\hline 3. & 265 & 1.027 \\
\hline 4. & 294 & 0.697 \\
\hline 5. & 314 & 0.834 \\
\hline 6. & 324 & 0.569 \\
\hline
\end{tabular}

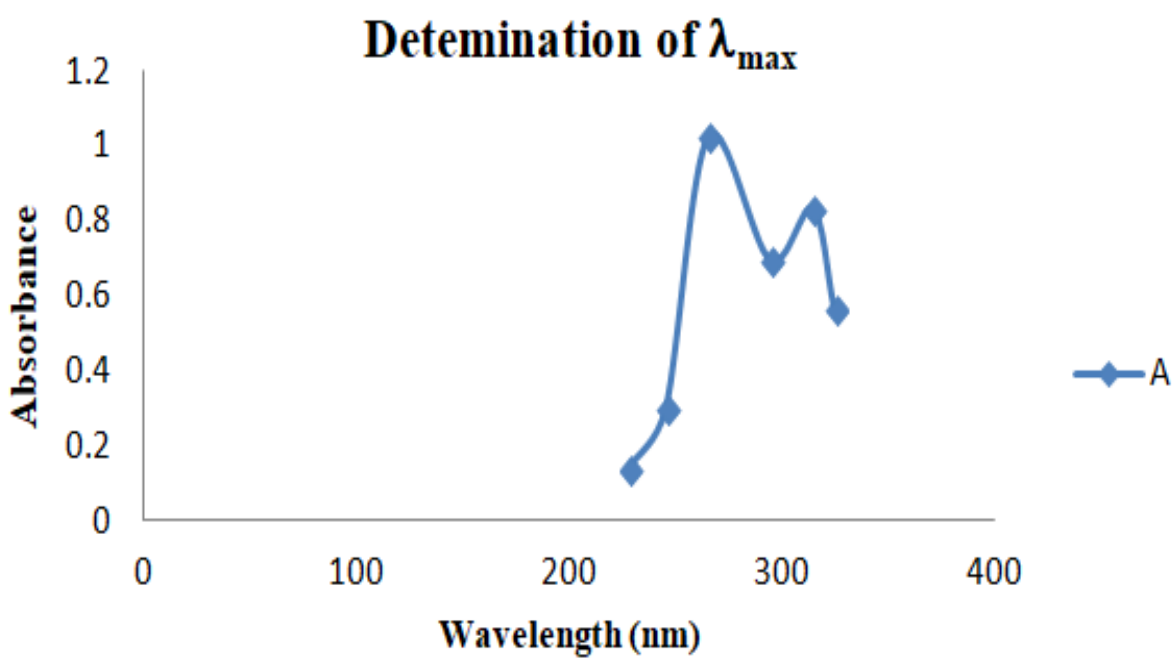

Fig.4: Determination of maxima wavelength $\left(\lambda_{\max }\right)$ 
Solubility of Ranitidine hydrochloride was determined in different solvents and the observations are shown in (table 5). The maximum solubility was found in DMSO and Water and insoluble in chloroform.

Table 5: Solubility Profile of Ranitidine HCL

\begin{tabular}{|l|l|l|}
\hline S. No. & Solvents & Solubility \\
\hline 1. & Distilled water & ++++ \\
\hline 2. & Acetic acid & ++ \\
\hline 3. & Ethanol & ++ \\
\hline 4. & 0.1 N HCL (pH-1.2) & ++ \\
\hline 5. & Methanol & ++ \\
\hline 6. & DMSO & +++++ \\
\hline 7. & Chloroform & + \\
\hline
\end{tabular}

Insoluble +; slightly soluble ++ ; freely soluble +++++ ; Soluble ++++

The in situ gelling system being one among them is a type of muco-adhesive drug delivery system principally capable of releasing drug molecule in a sustained manner affording relatively constant plasma profile.

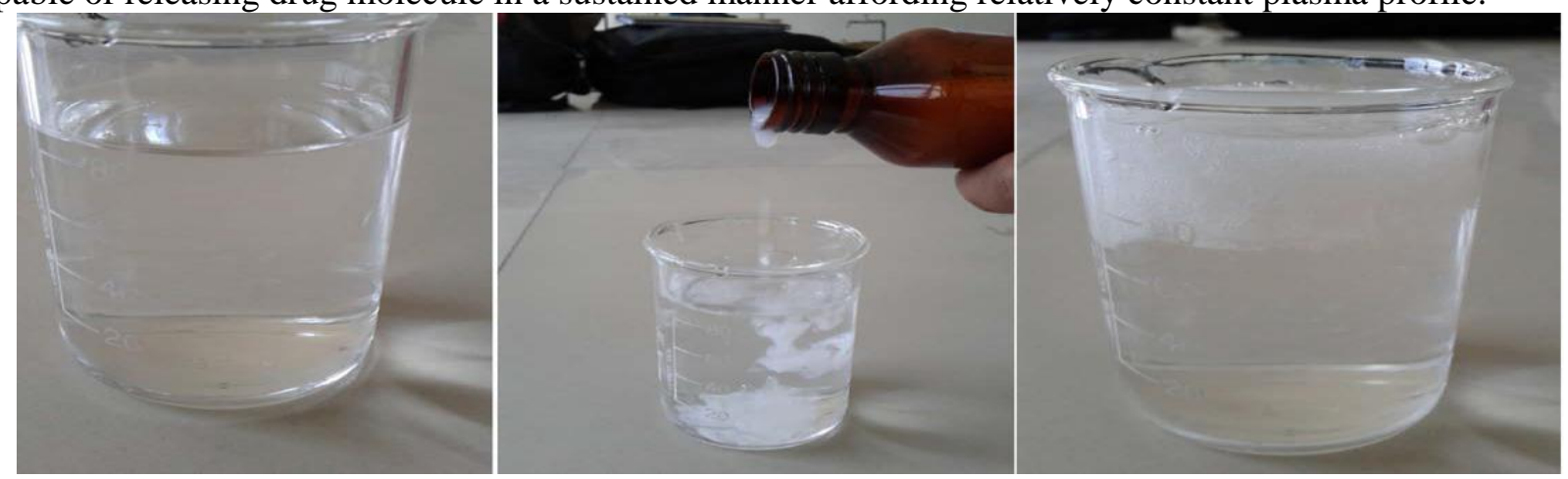

Fig.5: In-Situ Formation of Floating Gel

\section{Physical Appearance and pH}

All the prepared sodium alginate based in-situ solution of Ranitidine hydrochloride was checked for their clarity and the type of the solution. After administration of the prepared solution $(0.1 \mathrm{~N} \mathrm{HCl}$, $\mathrm{pH}$ 1.2) also checked the time required for gel formation and type of gel formed. The $\mathrm{pH}$ was measured in each of the solution of sodium alginate based in-situ solution of Ranitidine hydrochloride, using a calibrated digital $\mathrm{pH}$ meter.

\section{Viscosity}

The viscosity of the formulations increased with an increase in sodium alginate concentration. This phenomenon is a consequence of increasing chain interaction with an increase in polymer concentration. Calcium carbonate, which is the source of cations, increased the viscosity of the formulation. This change in viscosity is due to the proportional increase in the amount of dispersed calcium carbonate.

\section{Floating Behavior}

The buoyancy lag time varied with the formulation variables. Formulation F9 exhibited the least buoyancy lag time (40 s) while formulation F3 exhibited the highest lag time (59 s). The decrease in the buoyancy lag time of a formulation F9 can be attributed to the availability of an increased the concentration of calcium carbonate was increased, being entrapped in the formed gel to give rapid buoyancy. Irrespective of formulation variables, buoyancy duration was $>12$ hours. Gelling Capacity In-vitro gelling capacity of various formulation of in situ floating gel is reported.

\section{Drug Content}

The Drug content of all (DKF1-DKF10) formulations is given in (table 6). It ranges in between $98.09 \%$ - $99.79 \%$. The values are acceptable as per united state pharmacopeia standards. 
Table 6: Characterization of formulation of in-situ gel of R-HCL

\begin{tabular}{|c|c|c|c|c|c|c|c|c|c|c|}
\hline \multirow[t]{2}{*}{ Characterization } & \multicolumn{10}{|c|}{ Formulation code } \\
\hline & DKF1 & DKF2 & DKF3 & DKF4 & DKF5 & DKF6 & DKF7 & DKF8 & DKF9 & DKF10 \\
\hline pH & 7.4 & 7.3 & 7.3 & 7.2 & 7.1 & 7.2 & 7.1 & 6.9 & 7.0 & 7.1 \\
\hline Viscosity & 72 & 98 & 130 & 155 & 175 & 169 & 192 & 232 & 266 & 292 \\
\hline $\begin{array}{ll}\text { Floating lag time } \\
\text { (sec.) }\end{array}$ & 49 & 48 & 59 & 53 & 50 & 45 & 41 & 43 & 40 & 42 \\
\hline Floating-time (Hr.) & $>12$ & $>12$ & $>12$ & $>12$ & $>12$ & $>12$ & $>12$ & $>12$ & $>12$ & $>12$ \\
\hline Gelling capacity & ++ & ++ & ++ & ++ & +++ & +++ & +++ & +++ & +++ & ++++ \\
\hline Content uniformity & $\begin{array}{l}98.09 \\
\pm 0.38\end{array}$ & $\begin{array}{l}98.54 \\
\pm 0.70\end{array}$ & $\begin{array}{l}98.17 \\
\pm 0.81\end{array}$ & $\begin{array}{l}98.11 \\
\pm 0.34\end{array}$ & $\begin{array}{l}99.03 \\
\pm 0.21\end{array}$ & $\begin{array}{l}98.97 \\
\pm 0.54\end{array}$ & $\begin{array}{l}98.63 \\
\pm 0.87\end{array}$ & $\begin{array}{l}99.68 \\
\pm 0.21\end{array}$ & $\begin{array}{l}99.74 \\
\pm 0.18\end{array}$ & $\begin{array}{l}98.79 \\
\pm 0.41\end{array}$ \\
\hline
\end{tabular}

\section{In-Vitro Drug Release}

In-vitro drug release experiments were performed at $37 \pm 1^{\circ} \mathrm{C}$ in Dissolution test apparatus LAB INDIA DS 8000. The data obtained in In-vitro Drug release study are tabulated and represented graphically as:

Cumulative percentage drug release v/s time - (Zero order release kinetic)

Log cumulative percentage drug retained v/s time (First order release kinetics)

Cumulative percentage drug release v/s square root of time - (Higuchi model)

Log cumulative percentage drug release v/s Log time - (Koresmeyer data curve).

The zero order kinetics models data are shown in Table-7, 8 and graphically as Figure- 6 and 7 .

The first order release kinetics data are shown in Table-9, 10 and graphically as Figure-8 and 9.

The data of Higuchi model data are shown in Table11, 12 and graphically as Figure-10 and 11 .

The in-vitro release data were fitted into Korsemeyer equation and data is listed in Table-13, 14 and graphically as Figure-12 and 13.
The in-vitro drug releases of the in situ floating gel were carried in $(0.1 \mathrm{~N} \mathrm{HCl}, 1.2 \mathrm{pH})$ solution from 0 to $8 \mathrm{hrs}$ by using dissolution test apparatus USP Type II (Paddle Method). The samples were withdrawn at different time intervals and analyzed at $314 \mathrm{~nm}$. Percentage Cumulative drug release was calculated on the basis of mean amount of R-HCL present in the respective solution. The results obtained in the in vitro drug release for the formulations DKF1-DKF10 and Figure show in (tables) for \% cumulative drug release VS time. Formulation DKF1, DKF2, DKF3, DKF4, DKF5, DKF6, DKF7, DKF8, DKF9 and DKF10 released about $98.77 \%, 97.57 \%, 98.04 \%, 88.25 \%, 82.16 \%$, $81.25 \%, 78.16 \%, 79.36 \%, 72.15 \%, 61.03 \%$ of drug after 8 hrs Respectively. The results are shown in figure 5 indicate that the formulation, F6 which was prepared by the Sodium alginate (2\%) with Ranitidine showed minimum drug release after 8 hrs. Thus, the formulation (F9) has better result as comparison to others formulations as sustained release.

Table 7: In-vitro release data of Ranitidine HCL In-situ gel

\begin{tabular}{|l|l|l|l|l|l|}
\hline \multirow{2}{*}{$\begin{array}{l}\text { Time } \\
\text { Hr })\end{array}$} & \multicolumn{3}{|l}{ Zero order release kinetic } \\
\cline { 2 - 6 } & DKF1 & DKF2 & DKF3 & DKF4 & DKF5 \\
\hline 0 & 0.00 & 0.00 & 0.00 & 0.00 & 0.00 \\
\hline 1 & 17.56 & 18.09 & 21.45 & 11.23 & 20.31 \\
\hline 2 & 25.36 & 24.26 & 27.02 & 23.45 & 25.48 \\
\hline 3 & 45.25 & 47.13 & 45.16 & 25.12 & 31.55 \\
\hline 4 & 63.55 & 61.41 & 63.21 & 36.29 & 45.65 \\
\hline 5 & 74.25 & 75.28 & 76.33 & 44.09 & 58.63 \\
\hline 6 & 87.22 & 86.02 & 87.41 & 56.72 & 65.99 \\
\hline 7 & 91.88 & 92.14 & 90.25 & 72.36 & 75.66 \\
\hline 8 & 98.77 & 97.57 & 98.04 & 88.25 & 82.16 \\
\hline
\end{tabular}




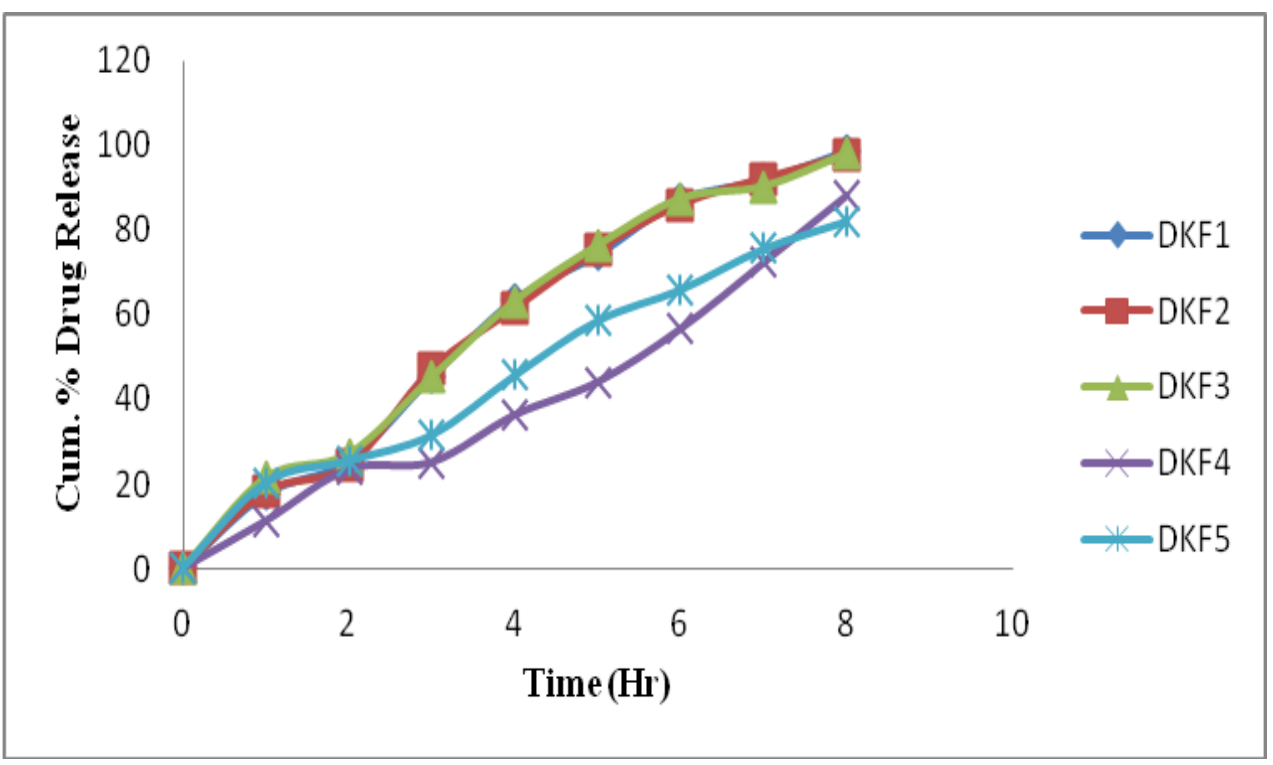

Fig. 6: In-vitro release curve of Ranitidine HCl In-situ gel -Zero Order Release

Table 8: In-vitro release data of Ranitidine HCI In-situ gel

\begin{tabular}{|c|c|c|c|c|c|}
\hline \multirow[t]{2}{*}{$\begin{array}{l}\text { Time } \\
(\mathbf{H r})\end{array}$} & \multicolumn{5}{|c|}{ Zero order release kinetic } \\
\hline & DKF6 & DKF7 & DKF8 & DKF9 & DKF10 \\
\hline 0 & 0.00 & 0.00 & 0.00 & 0.00 & 0.00 \\
\hline 1 & 19.35 & 26.34 & 20.73 & 23.31 & 16.78 \\
\hline 2 & 26.34 & 38.17 & 28.46 & 31.56 & 21.15 \\
\hline 3 & 32.54 & 44.71 & 40.54 & 38.84 & 35.09 \\
\hline 4 & 47.31 & 49.63 & 51.18 & 47.56 & 41.88 \\
\hline 5 & 59.25 & 55.43 & 56.78 & 52.31 & 47.36 \\
\hline 6 & 68.02 & 63.37 & 62.87 & 61.89 & 52.25 \\
\hline 7 & 76.69 & 69.73 & 71.02 & 67.43 & 57.18 \\
\hline 8 & 81.25 & 78.16 & 79.36 & 72.15 & 61.03 \\
\hline
\end{tabular}

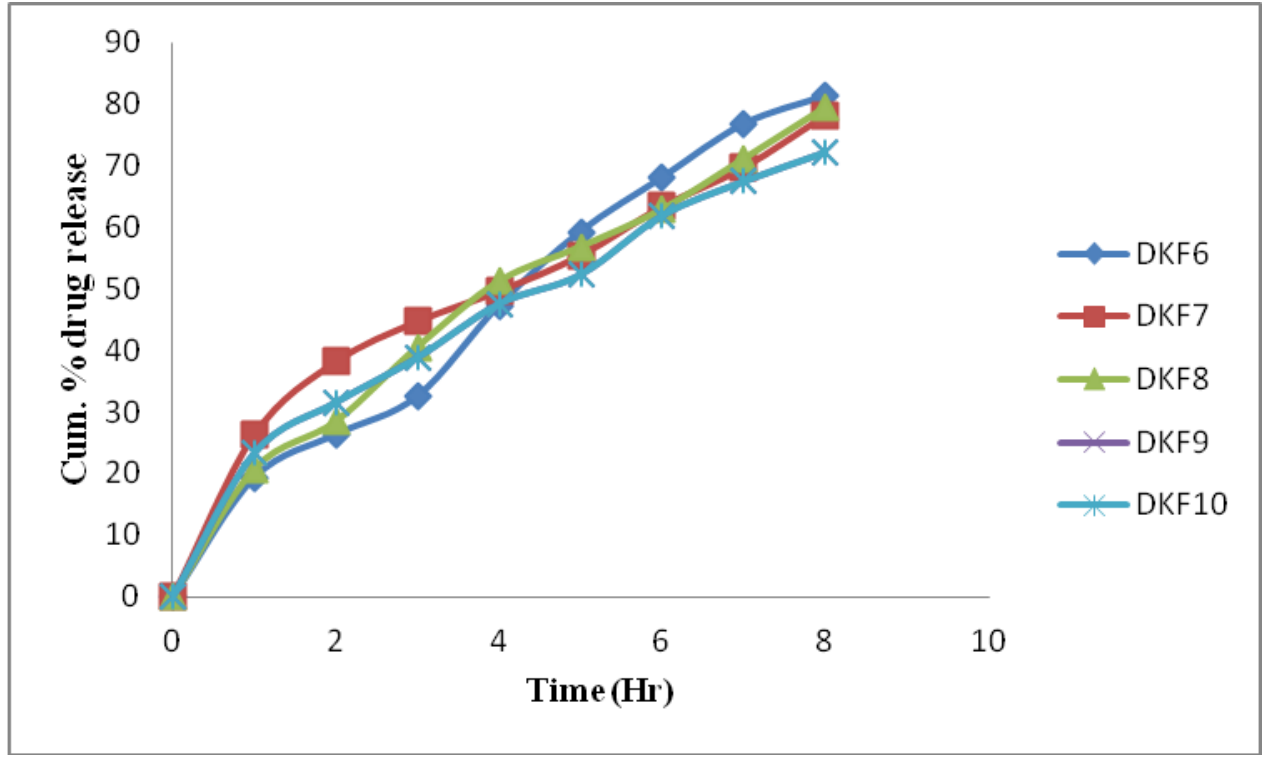

Fig. 7: In-vitro release curve of Ranitidine $\mathrm{HCl}$ In-situ gel -Zero Order Release 
Table 9: In-vitro release data of Ranitidine HCl In-situ gel

\begin{tabular}{|l|l|l|l|l|l|}
\hline \multirow{2}{*}{$\begin{array}{l}\text { Time } \\
(H r)\end{array}$} & \multicolumn{3}{|c|}{ first order release kinetic } & & \\
\cline { 2 - 6 } & DKF1 & DKF2 & DKF3 & DKF4 & DKF5 \\
\hline 0 & 2 & 2 & 2 & 2 & 2 \\
\hline 1 & 1.916 & 1.913 & 1.895 & 1.948 & 1.901 \\
\hline 2 & 1.873 & 1.879 & 1.863 & 1.884 & 1.872 \\
\hline 3 & 1.738 & 1.723 & 1.739 & 1.874 & 1.835 \\
\hline 4 & 1.562 & 1.586 & 1.566 & 1.804 & 1.735 \\
\hline 5 & 1.411 & 1.393 & 1.374 & 1.747 & 1.617 \\
\hline 6 & 1.107 & 1.146 & 1.1 & 1.605 & 1.532 \\
\hline 7 & 0.91 & 0.895 & 0.989 & 1.442 & 1.386 \\
\hline 8 & 0.09 & 0.386 & 0.292 & 1.07 & 1.251 \\
\hline
\end{tabular}

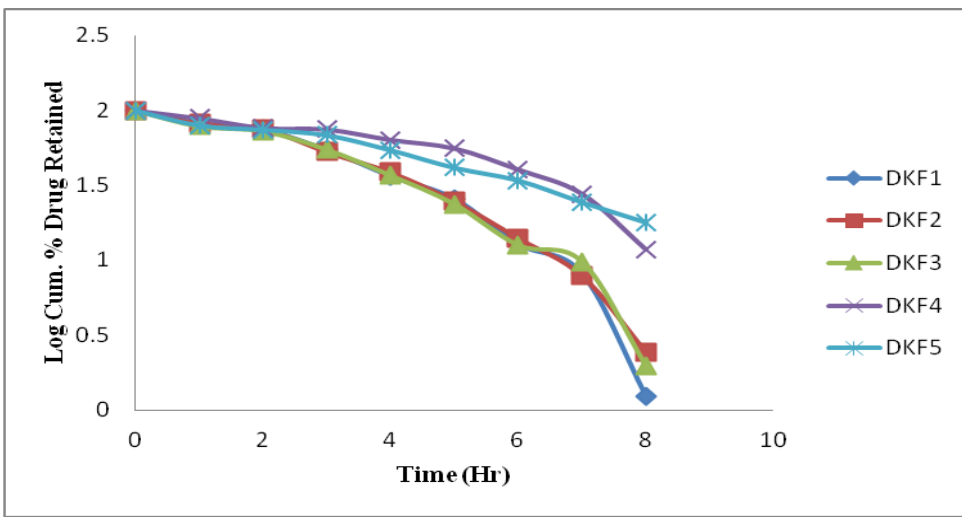

Figure 8: In-vitro release curve of Ranitidine HCI In-situ gel -First Order Release

Table 10: In-vitro release data of Ranitidine HCI In-situ gel

\begin{tabular}{|l|l|l|l|l|l|}
\hline \multirow{2}{*}{$\begin{array}{l}\text { Time } \\
(\text { Hr) }\end{array}$} & \multicolumn{5}{|c|}{ First order release kinetic } \\
\cline { 2 - 6 } & DKF6 & DKF7 & DKF8 & DKF9 & DKF10 \\
\hline 0 & 2 & 2 & 2 & 2 & 2 \\
\hline 1 & 1.907 & 1.867 & 1.899 & 1.885 & 1.920 \\
\hline 2 & 1.867 & 1.791 & 1.855 & 1.835 & 1.897 \\
\hline 3 & 1.829 & 1.743 & 1.774 & 1.786 & 1.812 \\
\hline 4 & 1.722 & 1.702 & 1.689 & 1.720 & 1.764 \\
\hline 5 & 1.610 & 1.649 & 1.636 & 1.678 & 1.721 \\
\hline 6 & 1.505 & 1.564 & 1.570 & 1.581 & 1.679 \\
\hline 7 & 1.368 & 1.481 & 1.462 & 1.513 & 1.632 \\
\hline 8 & 1.273 & 1.339 & 1.315 & 1.446 & 1.591 \\
\hline
\end{tabular}

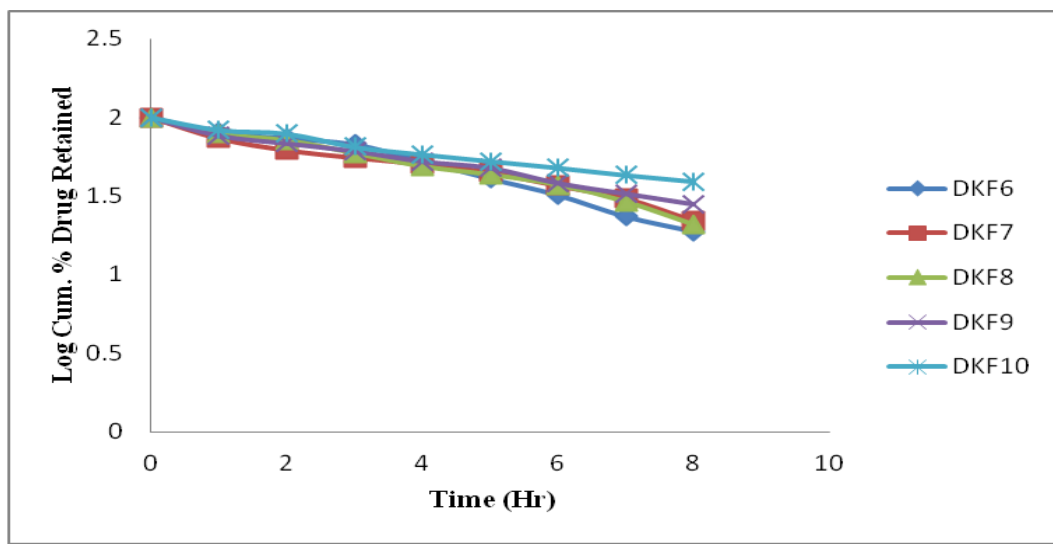

Fig. 9: In-vitro release curve of Ranitidine HCl In-situ gel -First Order Release 
Table 11: In vitro release data of Ranitidine HCl In-situ gel -Higuchi Model

\begin{tabular}{|l|l|l|l|l|l|}
\hline $\begin{array}{l}\text { Sq.root time } \\
\mathbf{t}^{\mathbf{2}}\end{array}$ & \multicolumn{6}{|l|}{ Cumulative percentage drug release } & \\
\cline { 2 - 6 } & DKF1 & DKF2 & DKF3 & DKF4 & DKF5 \\
\hline 0.000 & 0.00 & 0.00 & 0.00 & 0.00 & 0.00 \\
\hline 1.000 & 17.56 & 18.09 & 21.45 & 11.23 & 20.31 \\
\hline 1.414 & 25.36 & 24.26 & 27.02 & 23.45 & 25.48 \\
\hline 1.732 & 45.25 & 47.13 & 45.16 & 25.12 & 31.55 \\
\hline 2.000 & 63.55 & 61.41 & 63.21 & 36.29 & 45.65 \\
\hline 2.236 & 74.25 & 75.28 & 76.33 & 44.09 & 58.63 \\
\hline 2.449 & 87.22 & 86.02 & 87.41 & 56.72 & 65.99 \\
\hline 2.646 & 91.88 & 92.14 & 90.25 & 72.36 & 75.66 \\
\hline 2.828 & 98.77 & 97.57 & 98.04 & 88.25 & 82.16 \\
\hline
\end{tabular}

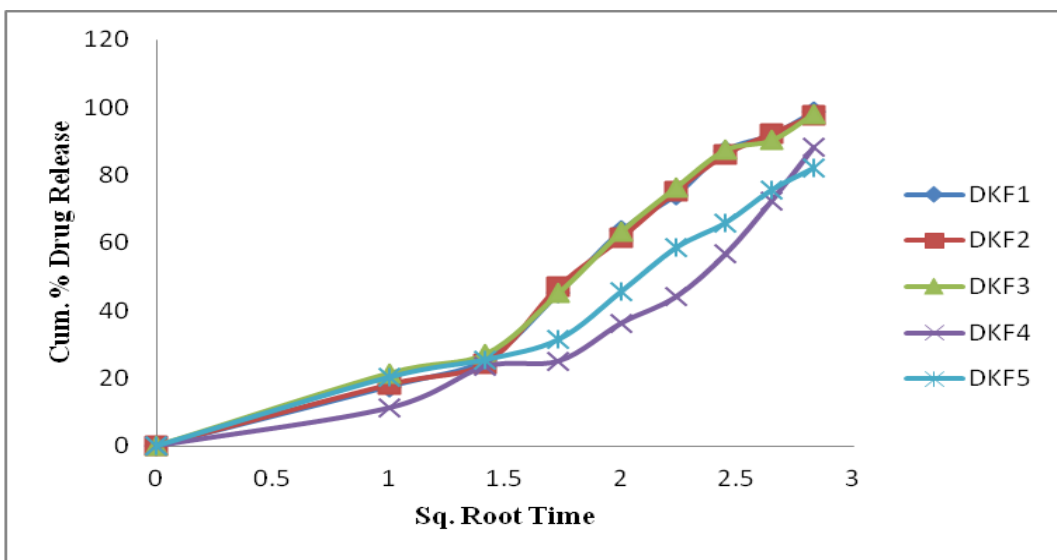

Fig. 10: In-vitro release curve of Ranitidine HCI In-situ gel - Higuchi Model

Table 12: In-vitro release data of Ranitidine HCl In-situ gel -Higuchi Model

\begin{tabular}{|l|l|l|l|l|l|}
\hline $\begin{array}{c}\text { Sq.root time } \\
\mathbf{t}^{\mathbf{2}}\end{array}$ & \multicolumn{6}{l}{ Cumulative percentage drug release } & \multicolumn{2}{l|}{} \\
\cline { 2 - 6 } & DKF6 & DKF7 & DKF8 & DKF9 & DKF10 \\
\hline 0.000 & 0.00 & 0.00 & 0.00 & 0.00 & 0.00 \\
\hline 1.000 & 19.35 & 26.34 & 20.73 & 23.31 & 16.78 \\
\hline 1.414 & 26.34 & 38.17 & 28.46 & 31.56 & 21.15 \\
\hline 1.732 & 32.54 & 44.71 & 40.54 & 38.84 & 35.09 \\
\hline 2.000 & 47.31 & 49.63 & 51.18 & 47.56 & 41.88 \\
\hline 2.236 & 59.25 & 55.43 & 56.78 & 52.31 & 47.36 \\
\hline 2.449 & 68.02 & 63.37 & 62.87 & 61.89 & 52.25 \\
\hline 2.646 & 76.69 & 69.73 & 71.02 & 67.43 & 57.18 \\
\hline 2.828 & 81.25 & 78.16 & 79.36 & 72.15 & 61.03 \\
\hline
\end{tabular}

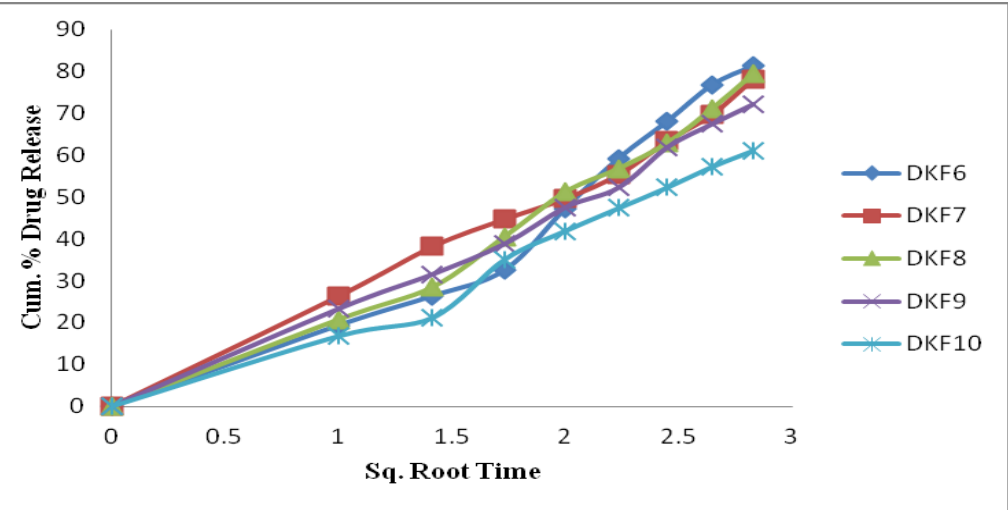

Fig. 11: In-vitro release curve of Ranitidine HCl In-situ gel - Higuchi Model 
Table 13: In-vitro release data of Ranitidine HCl In-situ gel -Korsemeyer Model

\begin{tabular}{|l|l|l|l|l|l|}
\hline \multirow{2}{*}{ Log time } & \multicolumn{5}{l}{ Log cumulative percentage drug release } \\
\cline { 2 - 6 } & DKF1 & DKF2 & DKF3 & DKF4 & DKF5 \\
\hline 0.000 & 0.000 & 0.000 & 0.000 & 0.000 & 0.000 \\
\hline 0.000 & 1.245 & 1.257 & 1.331 & 1.050 & 1.308 \\
\hline 0.301 & 1.404 & 1.385 & 1.432 & 1.370 & 1.406 \\
\hline 0.477 & 1.656 & 1.673 & 1.655 & 1.400 & 1.499 \\
\hline 0.602 & 1.803 & 1.788 & 1.801 & 1.560 & 1.659 \\
\hline 0.699 & 1.871 & 1.877 & 1.883 & 1.644 & 1.768 \\
\hline 0.778 & 1.941 & 1.935 & 1.942 & 1.776 & 1.819 \\
\hline 0.845 & 1.963 & 1.964 & 1.955 & 1.859 & 1.879 \\
\hline 0.603 & 1.995 & 1.989 & 1.991 & 1.946 & 1.915 \\
\hline
\end{tabular}

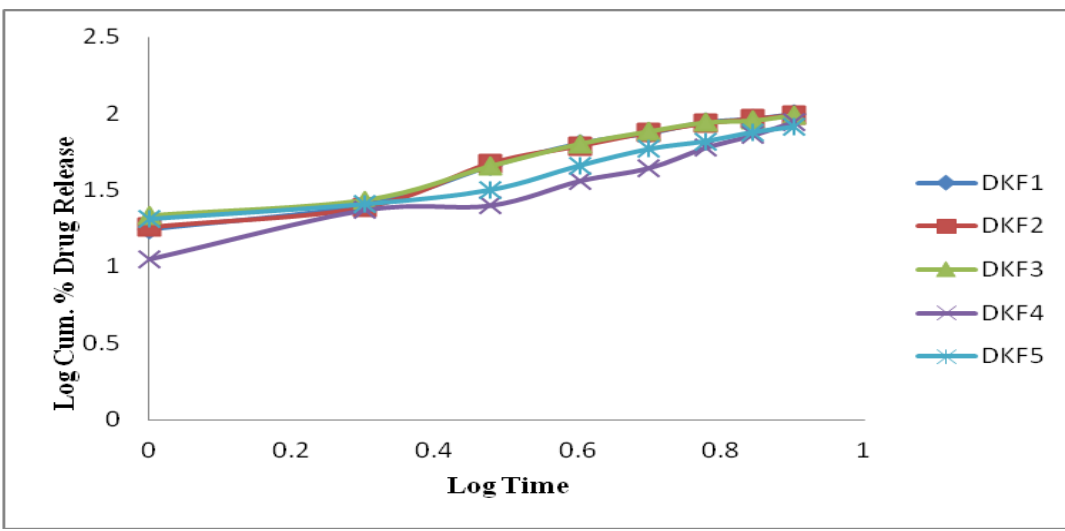

Fig. 12: In-vitro release curve of Ranitidine HCl In-situ gel - Korsemeyer Model

Table 14: In-vitro release data of Ranitidine HCl In-situ gel -Korsemeyer Model

\begin{tabular}{|l|l|l|l|l|l|}
\hline \multirow{2}{*}{ Log time } & \multicolumn{5}{|c|}{ Log cumulative percentage drug release } \\
\cline { 2 - 6 } & DKF6 & DKF7 & DKF8 & DKF9 & DKF10 \\
\hline 0.000 & 0.000 & 0.000 & 0.000 & 0.000 & 0.000 \\
\hline 0.000 & 1.287 & 1.421 & 1.317 & 1.368 & 1.225 \\
\hline 0.301 & 1.421 & 1.582 & 1.454 & 1.489 & 1.325 \\
\hline 0.477 & 1.512 & 1.650 & 1.608 & 1.589 & 1.545 \\
\hline 0.602 & 1.675 & 1.696 & 1.709 & 1.677 & 1.622 \\
\hline 0.699 & 1.773 & 1.744 & 1.754 & 1.719 & 1.675 \\
\hline 0.778 & 1.833 & 1.802 & 1.798 & 1.792 & 1.718 \\
\hline 0.845 & 1.885 & 1.843 & 1.851 & 1.829 & 1.757 \\
\hline 0.603 & 1.910 & 1.893 & 1.900 & 1.858 & 1.786 \\
\hline
\end{tabular}

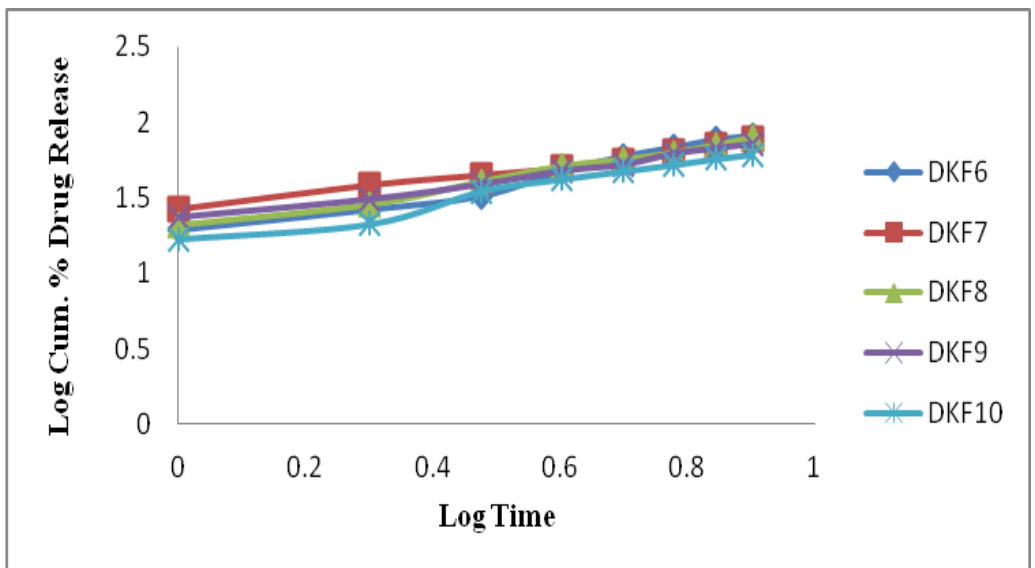

Fig. 13: In-vitro release curve of Ranitidine HCl In-situ gel - Korsemeyer Model 
Table 15: Fit of Various Kinetic Models for In-situ gel of R-HCL

\begin{tabular}{|l|l|l|l|l|}
\hline $\begin{array}{l}\text { Formulation } \\
\text { Code }\end{array}$ & $\begin{array}{l}\text { Zero Order } \\
\mathbf{R}^{\mathbf{2}}\end{array}$ & $\begin{array}{l}\text { First Order } \\
\mathbf{R}^{\mathbf{2}}\end{array}$ & $\begin{array}{l}\text { Higuchi Model } \\
\mathbf{R}^{\mathbf{2}}\end{array}$ & $\begin{array}{c}\text { Korsemeyer Model } \\
\mathbf{R}^{\mathbf{2}}\end{array}$ \\
\hline DKF1 & 0.975 & 0.861 & 0.939 & 0.977 \\
\hline DKF2 & 0.973 & 0.915 & 0.940 & 0.968 \\
\hline DKF3 & 0.970 & 0.892 & 0.946 & 0.965 \\
\hline DKF4 & 0.975 & 0.834 & 0.858 & 0.969 \\
\hline DKF5 & 0.985 & 0.963 & 0.939 & 0.953 \\
\hline DKF6 & 0.984 & 0.974 & 0.945 & 0.969 \\
\hline DKF7 & 0.929 & 0.972 & 0.992 & 0.888 \\
\hline DKF8 & 0.970 & 0.983 & 0.979 & 0.991 \\
\hline DKF9 & 0.952 & 0.991 & 0.990 & 0.789 \\
\hline DKF10 & 0.953 & 0.989 & 0.979 & 0.973 \\
\hline
\end{tabular}

Drug Release Kinetics Studies: The drug release data of Ranitidine were fitted to models representing, zero order, first order, Higuchi's and Korsemeyer's equation kinetics to know the release mechanisms. It was found that the in-vitro drug release of optimize batch F9 was best explained by zero order as the plots showed the highest linearity $\left(\mathrm{R}^{2}=0.991\right)$. The formulation are followed the zero order.

\section{Summary \& Conclusion}

The present investigation dealt with the formulation, optimization and evaluation of sodium alginate based in situ gel of ranitidine hydrochloride. Sodium alginate and calcium carbonate used as a polymer and cross-linking agent respectively.

The in situ formulations were exhibited well, viscosity, drug content and sustained drug release. This study reports that oral administration of aqueous solution containing sodium alginate result in formation of in situ gel. Such formulation are homogenous liquid when administration orally and become gel at the contact site.

The evaluation of the formulation is dependent upon accurate results obtained by analytical method used during the study. Accurate results require the use of standard and a calibration procedure. Hence, standard plots of Ranitidine hydrochloride were prepared in $(0.1 \mathrm{~N}$ HCL, $\mathrm{pH} \quad 1.2)$ solutions. Ranitidine hydrochloride was analyzed using UV spectrophotometer.

Two different were sodium alginate and calcium carbonate used as a polymer and cross-linking agent respectively in the formulation of in situ gel. Among different excipients used, sodium citrate, D-sorbitol etc. From the IR studies it may be concluded that the drug and carriers used undergo physical interaction there is no chemical change, and thus the gelling agent, cross-linking agent and other excipients are suitable for formulation of in situ gel of ranitidine hydrochloride.

Formulation DKF1, DKF2, DKF3, DKF4, DKF5, DKF6, DKF7, DKF8, DKF9 and DKF10 released about 98.77, 97.57, 98.04, 88.25, 82.16, 81.25, $78.16,79.36,72.15$ and 61.03 of drug after $8 \mathrm{hrs}$ respectively. Indicate that the formulation, DKF9 which was prepared by the Sodium alginate $(2 \mathrm{gm})$ with Ranitidine Hydrochloride showed minimum drug release (sustained drug release) after 8 hrs. Thus, the formulation (DKF9) has better result as comparison to others formulations.

The optimized formulation was found to be stable at room temperature for 90 days showed no significant change in the content of Ranitidine hydrochloride. No significant change was observed in the content uniformity, Viscosity and drug release of the In situ gel. All other parameters were also observed to be comparable. It could be concluded from study that optimized formulation was stable at room temperature.

\section{References}

1. Shah S., Upadhyay P., Parikh D., Shah J., Insitu gel: a novel approach of gastroretentive drug delivery. Asian journal of biomedical and pharmaceutical sciences. (2012) 2(8):1-8.

2. Parekh H.B., Rishad J., Jivani N.P., Patel L.D., Ami M., Krunal S., Novel in-situ polymeric drug delivery system: a review. Journal of Drug Delivery \& Therapeutics (2012) 2(5): 136-145.

3. Shah S.H., Patel J.K., Patel N.V., Stomach specific floating drug delivery system: a review. International Journal of Pharm. Tech. Research. (2009) 1(3):623-633.

4. Bhardwaj L, Sharma P.K., Malviya R., A Short Review on Gastro Retentive Formulations for Stomach Specific Drug Delivery: Special Emphasis on Floating In 
situ Gel Systems. African Journal of Basic \& Applied Sciences. (2011) 3 (6): 300-312.

5. Watarukubo, Miyazaki S., Attwood D., Oral sustained delivery of paracetamole from insitu gelling gellan and sodium alginate formulation. International journal of pharmaceutics. (2013) 258, 55-64.

6. Itoh K., Hatakeyama T., Shimoyama T., Miyazaki S., In situ gelling formulation based on methylcellulose/pectin system for oralsustained drug delivery to dysphagic patients. Drug Development and Industrial Pharmacy.(2011):37(7): 790-797.

7. Kumar S.A., Dubey V., Arora V., Role of natural polymers used in floating drug delivery system. Journal of Pharmaceutical and Scientific Innovation. (2012) 1(3):11-15.

8. Gaikwad V., "Formulation And Evaluation of In-Situ Gel of Metoprolol Tartrate For Nasal Delivery" Journal Of Pharmacy Research; 2010: 3(4);788-793

9. Chandra Mohan S., N. Manjunatha, Patel K., M. K. Samanta, Bhaskaran A., "Design And Development Of Oral Sustained In Situ Gelling System Of Famotidine“. Indian Journal of Novel Drug Delivery; 2009; 1(1): 42-46

10. Qiu Y., Park K., "Environment-sensitive hydrogels for drug delivery. Adv. Drug Deliv. Rev. (2001) 53: 321-339.

11. Miyazaki S., Suzuki S., Kawasaki N., Endo K., Takahashi A., In-situ gelling xyloglucan formulations for sustained release ocular delivery of pilocarpine hydrochloride. Int. J. Pharm. (2001) 229:29-36.

12. Brijesh S. D.,Avani F. A., Madhabhai M. P., Gastroretentive Drug Delivery System of Ranitidine Hydrochloride: Formulation and In Vitro Evaluation. AAPS Pharm. Sci. Tech. (2004) 5(2):1-6.

13. Ramesh K., Rao B.P., Reddy G.J., Beny B., Rajarajan S., Design, Optimization and evaluation of peroral in situ gel containing
Ranitidine HCl. Am. J. Pharma. Tech. Res. (2014) 4(2):733-744.

14. Hasan M.J., Kamal B.A., Formulation And Evaluation of Ranitidine Hydrochlorideas Floating In Situ Gel. International Journal of Pharmacy and Pharmaceutical Sciences. (2014) 6(2):401-405.

15. Shankar S.J, Kalikonda A., pH induced in-situ gel formulation of lomefloxacin $\mathrm{HCl}$. Universal journal of pharmacy. (2014) 3(1):38-43.

16. Nassour L., Hasan I., El-Hammadi M. And Abboud H., Floating In-Situ-Gelling Gellan Formulations of Metformin Hydrochloride. Journal of Chemical and Pharmaceutical Research. (2014) 6(7):1509-1517.

17. Verma S.P., Singh K.P., Novel Polymeric In Situ Gel Forming System for Ophthalmic Drug Delivery. International Journal of Drug Delivery Technology. (2014) 4(1):1-13.

18. Parekh K.S., Shah K.V., Formulation Development and Evaluation of Oral In-Situ Floating Gel of Domperidone. Pharma Science Monitor An International Journal of Pharmaceutical Sciences. (2013) 4(3):228246.

19. Kushal P., Agrawal P., Dashora A., Sahu D., Formulation and Evaluation of Oral Floatable In-Situ Gel of Ranitidine Hydrochloride. Journal of Drug Delivery \& Therapeutics. (2013) 3(3):90-97.

20. Reddy K.R., Yadav M.R.S., Reddy P.S., "Preparation And Evaluation Of Aceclofenac Ophthalmic In-Situ Gels" Journal Of Chemical, Biological And Physical Sciences; 2011; 1(2): 289-298.

21. Jayswal B.D., Yadav V.T., Patel K.N., Patel B.A., Patel P.A., "Formulation And Evaluation Of Floating In Situ Gel Based Gastro Retentive Drug Delivery Of Cimetidine" International Journal For Pharmaceutical Research Scholars; 2012:1(2), 327-337. 